SYLWIA JASKULSKA

Uniwersytet im. Adama Mickiewicza

$w$ Poznaniu

\title{
KREOWANIE DOŚWIADCZEŃ LIMINALNYCH W SZKOLE Z WYKORZYSTANIEM METODY DRAMY EDUKACYJNEJ
}

\begin{abstract}
Jaskulska Sylwia, Kreowanie doświadczeń liminalnych w szkole z wykorzystaniem metody dramy edukacyjnej [Creating Liminal Experiences at School with the Method of Educational Drama]. Studia Edukacyjne nr 42, 2016, Poznań 2016, pp. 155-176. Adam Mickiewicz University Press. ISSN 1233-6688. DOI: $10.14746 /$ se.2016.42.9

The aim of the paper is to consider the possibility of creating liminal experiences at school with the method of educational drama and the pedagogical potential of such activities. Treated as the medium phase of rite, I define liminality in line with Arnold van Genepp and Victor Turner. By claiming that for many reasons school is a liminal space and showing that the fact that this function is neglected at the cost of the transmission function is a problem, I present drama as a possible antidote.
\end{abstract}

Key words: school, drama method, liminality

\section{Wprowadzenie}

Niniejszy tekst traktuję jako głos $\mathrm{w}$ dyskusji nad rolą dramy w edukacji, a jego celem jest refleksja nad kreowaniem doświadczeń liminalnych w szkole z wykorzystaniem tej metody. Zanim przejdę do liminalności jako takiej, zdefiniuję pojęcia drama i rytuał oraz pokażę relacje, $w$ jakich je postrzegam. Pojęciem łączącym je $\mathrm{w}$ performatywnym ujęciu, jakie przyjmuje w tym tekście, jest teatr. Liminalność jako fenomen o dużym potencjale pedagogicznym ukazuję więc poprzez zestawienie rytuału i teatru oraz dramy edukacyjnej i teatru. 


\section{Drama w edukacji}

\section{Za Krystyną Pankowską definiuję dramę jako:}

metodę dydaktyczno-wychowawczą angażującą w działanie ucznia całą jego wiedzę o świecie, tworzącą nowe jej jakości w związku z wykorzystywaniem wyobraźni, emocji, zmysłów, intuicji. Podstawą dramy jest rozgrywanie w różnych możliwych rolach nowych, nieznanych wcześniej, nieraz bardzo trudnych sytuacji, w celu ich zrozumienia, uwewnętrznienia, zdobycia bądź pogłębienia wiedzy o świecie, o sobie, o innych ludziach ${ }^{1}$.

Drama w szkole to sposób oddziaływania edukacyjnego i wychowawczego. Jest zatem wykorzystywana przynajmniej w dwójnasób - jako wsparcie rozwoju uczniów (także w kontekście funkcjonowania w grupie), jak też jako jedna $z$ metod $w$ nauczaniu². Podstawowe założenie, na którym są osadzone teoria i praktyka dramy, dotyczy roli aktywności w życiu człowieka - świat poznaje się właśnie przez własną w nim aktywność3. Drugie założenie dotyka zagadnienia indywidualizmu każdego człowieka. Za twórcą tej metody, Brianem Wayem ${ }^{4}$, można powiedzieć, że rozwój dramy nie byłby możliwy bez przyjęcia idei indywidualizmu i zrozumienia, że każdy człowiek jest unikatowy.

Drama to typ zajęć, $w$ którym zadania wykonywane są na granicy fikcji i rzeczywistości poprzez przyjmowanie ról.

Istota stosowania dramy polega na stwarzaniu sytuacji, w której uczniowie mogliby się identyfikować z innymi osobami czy rzeczami, zagrać rolę jakiejś postaci, wczuć się w inną osobowość czy w kondycję innego istnienia. Celem metody jest pogłębianie rozumienia motywacji różnych zachowań, wyrabianie umiejętności współżycia oraz pracy w grupie, a także wyrabianie wrażliwości, rozbudzanie wyobraźni i refleksji ${ }^{5}$.

Podstawą dramy jest wchodzenie w rolę, ale używane są też inne techniki dramowe, jak na przykład rzeźba, stop-klatka, rysowanie, taniec, rozmowa, ćwiczenie zmysłów 6 .

${ }^{1}$ K. Pankowska, Pedagogika dramy. Teoria i praktyka, Warszawa 2000, s. 22.

${ }^{2}$ G. Özbek, Drama in education: key conceptual features, Journal of Contemporary Educational Studies, 2014, 1, s. 50.

3 Zob. M. Królica, Drama i happening w edukacji przedszkolnej, Kraków 2009, s. 11; G. Özbek, Drama in education, s. 48.

4 B. Way, Development through drama, London 1968.

5 K. Pankowska, Drama - zabawa i myślenie, Warszawa 1990, s. 39.

${ }^{6}$ Zob. np. M. Antczak, Techniki dramy w teorii i praktyce nie tylko dla nauczycieli bibliotekarzy, Warszawa 2004, s. 13 i n. 
Potocznie (i błędnie) uważa się, że drama to tak zwane "scenki” odgrywane podczas lekcji. $Z$ tego powodu pojęcie dramy jest nadużywane. Określa się jej mianem wszelkie parateatralne formy pojawiające się podczas zajęć szkolnych, które nie zawsze są dramą. W związku z takim stanem rzeczy $\mathrm{w}$ poszukiwaniach definicyjnych należy sięgać $\mathrm{z}$ pewnością do relacji dramy i teatru, a przyjęte $\mathrm{w}$ tym względzie założenia mogą dopełnić i ujednoznacznić definicję dramy, która jest dla moich rozważań kluczowa.

Teoretycy i praktycy dramy nie są zgodni co do charakteru wspomnianej relacji. Na przykład, w odniesieniu do dramy edukacyjnej w Polsce widać dwa wyraźnie odmienne stanowiska. Drama to według Anny Dziedzic specyficzna forma artystyczna zbliżona do teatru, wykorzystująca jego techniki i środki. Z kolei Krystyna Pankowska konsekwentnie postuluje oddzielenie pojęciowe teatru od dramy. Ich traktowanie jako zbieżne prowadzi bowiem, według Pankowskiej, do niepotrzebnych uproszczeń7. Definicja Krystyny Pankowskiej jest antropologiczna. Pankowska postrzega dramę jako zmaganie się z życiem, próbowanie życia. To bardzo szerokie ujęcie, w którym edukacyjna rola dramy polega na umożliwianiu trenowania różnych sytuacji życiowych, wypróbowywania

swoich możliwości, swoich reakcji w zetknięciu się z trudnymi problemami bądź też badaniu swojej postawy $\mathrm{w}$ niecodziennych zdarzeniach, kontekstach czy relacjach międzyludzkich ${ }^{8}$.

Brian Way również przeciwstawia dramę teatrowi. Różni je, według niego, między innymi stosunek widza i aktora. W teatrze ważna jest komunikacja między jednymi i drugimi. W dramie widz pełni drugorzędną rolę. Najważniejsze jest doświadczenie odtwarzającego. Podobnie uważa również Patrice Baldwin, która w rozmowie z Kamilą Witerską zauważa:

teatr jest zazwyczaj przygotowany i skierowany do zewnętrznej publiczności, a drama służy jej uczestnikom (którzy mogą być publicznością dla siebie nawzajem w trakcie trwania dramy). Uczestnicy dramy nie wiedzą jak ona się rozwinie, ponieważ oni sami rozwijają ją wspólnie poprzez medium, jakim jest sama drama9.

Przekłada się to na pedagogiczne zastosowanie dramy. Dzieci i młodzież nie są $\mathrm{w}$ większości zdolne, powiada Way, do kontaktu z widzem, a wymu-

7 Zob. także K. Nowak-Wolna, Od dramatu teatralnego do dramy edukacyjnej, [w:] Od teatru pedagogicznego do teatru terapeutycznego, red. W. Sikorski, A. Sikorska, Warszawa 2014, s. 50.

8 K. Witerska, Drama. Przewodnik po koncepcjach, technikach i miejscach, Warszawa 2014, s. 16.

${ }^{9}$ Tamże, s. 19. 
szanie tego kontaktu niszczy doświadczenie dramatyczne ${ }^{10}$. Dla Johna Somersa z kolei drama to kontinuum, bowiem nie sposób opowiedzieć się za jednym jego końcem, czyli dramą, której najważniejszym celem jest rozwój uczestników, a drugim, na którym stoją cele bliższe sztuce teatralnej11.

$\mathrm{W}$ dramie edukacyjnej ważna jest improwizacja, wchodzenie $\mathrm{w}$ rolę, nie zaś jej odgrywanie, liczy się doświadczenie uczestników. Jednak bliska jest ona teatrowi poprzez stylizację, częściowe przynajmniej scenariusze, odgrywanie jakiś historii. Nawet Pankowska pisze, że

podobnie $\mathrm{w}$ teatrze, jak i w dramie chodzi o jakiś wycinek rzeczywistego ludzkiego doświadczenia, a uczestnicy, ubrani w kostiumy swoich ról, działają bądź to zgodnie z symbolicznym wyobrażeniem odgrywanej postaci, bądź zgodnie z narzuconym tekstem ${ }^{12}$.

Drama jest więc bliska teatrowi, nie jest $\mathrm{z}$ nim jednak tożsama i należy mieć świadomość dzielących te pojęcia różnic. Ze względu na rolę, jaką pełnią uczestnicy dramy, jest ona bliższa rytuałowi niż teatrowi i to w obrębie tej relacji lokuję dalsze dywagacje.

\section{Rytual - teatr - drama}

Rytuał to pojęcie właściwe antropologii, które stało się kategorią analityczną innych nauk, takich jak socjologia, psychologia, czy pedagogika. Nie ma jednoznacznej definicji rytuału, jak to bowiem w przypadku kategorii o tak bogatej historii bywa, wszystko zależy od ujęcia, jakie przyjmujemy. Rytuał początkowo łączony ze społecznościami plemiennymi i ze sferą religijną, dziś przeżywa prawdziwy rekonesans w naukach społecznych i humanistycznych. Przez pryzmat ich rytuałów bada się instytucje (np. szkołę), media, mówi się o rytuałach politycznych, rytuałach codzienności itp. Na potrzeby tego tekstu przyjmuję dość uniwersalną definicję rytuału, którą buduję poprzez wymienienie jego cech za Royem Rappaportem.

Cechy konieczne, by jakieś zjawisko nazwać rytuałem, to według autora: kodowanie przez osoby niebędące wykonawcami rytuału, formalność, niezmienność, wykonanie ${ }^{13}$. Po pierwsze więc, rytuał służy przekazowi warto-

10 B. Way, Drama w wychowaniu dzieci i młodzieży, przekł. K. Pankowska, E. Nerwińska, Warszawa 1995, s. 18.

${ }^{11}$ K. Witerska, Drama. Przewodnik po koncepcjach, s. 64.

12 K. Pankowska, Pedagogika dramy, s. 78.

${ }^{13}$ R. Rappaport, Rytuat i religia w rozwoju ludzkości, przekł. A. Musiał, T. Sikora, A. Szyjewski, Kraków 2008, s. 62 i n. 
ści. Można mówić o swego rodzaju skrypcie rytualnym, ponieważ dokładnie wiadomo co i jak będzie odtwarzane, ale ten skrypt jest zapisany w tradycji, wykonujący go nie są jego autorami. Elementy rytuału, o czym mówi druga z wymienionych przez Roya Rappaporta cech, są powtarzane bardzo drobiazgowo, stereotypiczne i są stylizowane ${ }^{14}$. Można mówić o stałych parametrach każdego rytuału, czyli o czasie (konkretna pora roku, dnia itp.), miejscu, rekwizytach, atmosferze. Rytuał $\mathrm{w}$ tym podobny jest do przedstawienia teatralnego, a tym różni się od gry, że wiadomo, jak się zacznie i jak zakończy - jest niezmienny ( $w$ pewnych granicach oczywiście) ${ }^{15}$. Scenariusz przedstawienia teatralnego, przynajmniej $\mathrm{w}$ tradycyjnie rozumianym teatrze, jest wykonywany bardzo skrupulatnie. $W$ obrzędzie także, ale inna jest rola aktora teatralnego, a inna uczestników rytuału. To pewne uproszczenie, ale można powiedzieć, że aktora mniej osobiście dotyka rola, w której jest. $Z$ pewnością nie jest tak, że grane role $\mathrm{w}$ żaden sposób nie rzutują na aktora, rytuał jednak realnie wpływa na życie jego uczestników, jest performatywnym elementem ich życia, dzieje się, jak teatr na granicy fikcji i rzeczywistości, ale jest trochę tej rzeczywistości bliższy. Stwierdzenie to domaga się dopowiedzenia, bowiem rytuał nie jest trikiem magika, a jego skuteczność nie jest fizyczna. Rytuał nie ma, według Roya Rappaporta, fizycznej mocy sprawczej, ale kieruje „na to, na co chce wpływać, czynniki i siły innego rodzaju"16. Skuteczność rytuału nie jest zatem widoczna i oczywista, ale oparta na sile wywodzącej się ze słowa i z emocji.

Obrzędy są definiowane jako powtarzalne zachowania, którym towarzyszy przekonanie, że ich znaczenie wykracza poza wykonywane czynności ${ }^{17}$. Przygotowywanie jakiegoś posiłku, którego spożycie jest elementem obrzędu nie ma więc na celu zaspokojenia głodu ludzi, którzy biorą udział w rytuale. Pokarm, czy każdy inny obrzędowy rekwizyt, niesie więcej treści symbolicznych niż znaczeń fizycznych. Henri Hubert i Marcel Mauss w Zarysie ogólnej teorii magii odróżniają skuteczność obrzędów od skuteczności mechanicznej, właściwej technice, w odniesieniu do której „wytwory są jednorodne ze środkami”18. Skuteczność obrzędów jest swoista, bo „poszczególne akty rytualne oraz używane w nich środki są zasadniczo niejednorod-

14 Tamże, s. 64.

15 S. Jaskulska, K. Motyl, Gra o Tron? Rytuaty i gry w optyce teorii antropologicznej Clifforda Geertza i analizy transakcyjnej. Przyczynek do badania codzienności szkoty, Studia Edukacyjne, 2014, 31, s. 76.

${ }^{16}$ R. Rappaport, Rytuat i religia, s. 83.

17 J.D. Eller, Antropologia kulturowa. Globalne sity, lokalne światy, przekł. A. Gąsior-Niemiec, Kraków 2012, s. 353.

${ }_{18}$ M. Mauss, H. Hubert, Zarys ogólnej teorii magii, [w:] Socjologia $i$ antropologia, red. M. Mauss, przekł. M. Król, J. Szacki, K. Pomian, Warszawa 1973, s. 15. 
ne $\mathrm{z}$ celem osiąganym przez cały obrzęd - należą do odmiennych ciągów przyczynowo-skutkowych"19. Przygotowanie posiłku, używane do tego przedmioty, a także sposób spożycia stają się elementem ciągu rytualnego.

Ostania cecha rytuałów wymienionych przez Rappaporta znów pokazuje bliski związek obrzędów i przedstawień teatralnych. Rytuał musi być wykonywany, nie można zatem podtrzymywać rytuałów, podobnie jak teatru, tylko w przekazie ustnym. Ronald L. Grimes nazywa to żywotnością rytuałów. Tylko wtórnie mogą one istnieć w tekstach, scenariuszach, opowieściach. Pierwotnie dzieją się $\mathrm{w}$ trakcie odtwarzania ${ }^{20}$. Z wykonaniem łączy się pojęcie ekspresji. Za Edmundem Leachem można mówić o rytuale właśnie jako o ekspresyjnym aspekcie zachowania. Eric W. Rothenbuhler przypisuje temu zachowaniu nadmiar estetyczny i nadmiar stylizacji (to wyróżnia rytuał spośród innych zachowań ${ }^{21}$, a zbliża do przedstawienia teatralnego).

Podobieństwa teatru i rytuału prowadzą do obecnej w performatyce tezy, iż ten drugi jest źródłem pierwszego. W teatrze współczesnym można odnaleźć tęsknotę za rytuałem jako za pramatką czy wspólnym początkiem. Przykładem może być działalność Petera Schumanna, Niemca z pochodzenia, który w latach 60. XX wieku przeniósł się do Nowego Yorku i tam założył teatr, który miał być żywą reakcją i komentarzem ówczesnych problemów, z którymi borykała się Ameryka, formą protestu wobec polityki USA (między innymi wobec wojny $w$ Wietnamie). Wzorów dla swojego teatru Schumann szukał $w$ rytuałach i tworzył je wraz $\mathrm{z}$ widzami. Raz do roku na farmie Schumanów odbywał się zjazd widzów, podczas którego powstawały teatralne improwizacje. Wszystko to miało charakter ni to jarmarku, ni cyrku, ni festiwalu czy awangardowego teatru ${ }^{22}$. Jak opisuje to zjawisko Henryk Jurkowski:

przedstawienia zaczynały się o zmroku pochodem, w którym uczestniczyły dziesiątki wykonawców, posługujących się gigantycznymi lalkami z butafory i różnorodnych tkanin. Każde z nich składało się z czterech „działań”. Pierwsze przedstawiało „naturalny porządek uniwersum”. Uczestnicy nieśli wokół amfiteatru ogromną lalkę, zwaną Twarzą Boga, śpiewając tradycyjny hymn pochwalny. Drugie "działanie" poświęcone było ważnym wydarzeniom historycznym i politycznym zgodnie z moralistyczną optyką Schumana. Trzecie przedstawiało odwieczną walkę dobra ze złem, z epizodami wielkiego tańca śmierci. W scenie końcowej, tuż przed zapadnięciem zmierzchu, pojawiała się gigantyczna postać Matki Ziemi. W ręku trzymała po-

19 T. Jerzak-Gierszewska, Religia a magia. Klasyczne koncepcje antropologiczne, Poznań 1995, s. 107.

20 R.L. Grimes, Beginnings in Ritual Studies, Columbia 1995, s. 67.

${ }^{21}$ E. Rothenbuhler, Komunikacja rytualna. Od rozmowy codziennej do ceremonii medialnej, przekł. J. Barański, Kraków 2006, s. 36.

${ }^{22}$ H. Jurkowski, Materiat jako wehikut treści rytuału, Warszawa 2011, s. 344-346. 
chodnię, za pomocą której podpalała zgromadzone na arenie pałuby, przedstawiające siły negatywne. Nad ogniem unosiły się białe ptaki, animowane przez lalkarzy, przy melodyjnych dźwiękach domowej orkiestry ${ }^{23}$.

W odniesieniu do takich fenomenów kulturowych pytać można wręcz, czy to jeszcze teatr, czy już rytuał? A może: czy jeszcze rytuał, czy już teatr? Polskim przedstawicielem nurtu, w którym poszukuje się pola interferencji antropologii i teatru, był Jerzy Grotowski24, a jego działania także nazwać można laboratorium teatralnym lub rytualnym.

Teatr jest gatunkiem poligenetycznym, ale jednym z jego źródeł mogą być rytuały.

Teatrolodzy, śledząc w różnych źródłach antropologicznych genezę mimetycznych zachowań w rolach, odnajdują je np. w pantomimie myśliwskiej, ceremoniałach totemicznych, inicjacjach (...) rytuałach wegetacyjnych czy nawet w szamanizmie ${ }^{25}$.

Takie antropologiczne podejście wskazuje, że teatr nie powinien być lokowany wyłącznie w dziedzinie sztuk pięknych, ale łączy się też z pracą, magią, religią, medycyną, polityką ${ }^{26}$. Dystynkcję między rytuałem a teatrem postrzega Richard Schechner nie jako rozdźwięk w formie, ale w funkcji. Rozróżniać woli on rozrywkę i skuteczność, nie zaś teatr i rytuał. Przedstawienia kulturowe nie pełnią nigdy czystej funkcji rozrywkowej lub skuteczności, są jednak jednej albo drugiej bliższe i na tym zasadza się różnica27. W rytuale jest scenariusz, jest publiczność, ale przesuwa się punkt ciężkości na osobiste doświadczenie aktora. $W$ teatrze chodzi przede wszystkim o sztukę, ale skoro nie tylko, blisko jest do niego tak rytuałowi, jak i dramie. Gdyby przyjąć upraszczające, co nie znaczy że nieprawdziwe, kontinuum rytuał - teatr - drama, można powiedzieć, że ostatnia jest jakby powrotem do pierwszego, tęsknotą za mimetyzmem w służbie codziennego życia bardziej, niż sztuka, ale wszystkie one, w różnym jedynie natężeniu dostarczają doświadczeń performatywnych niezbędnych człowiekowi do rozwoju. Klarowną reprezentacją tego związku są, w moim odczuciu, rytuały przejścia i, do czego w swoim wywodzie zmierzam, pojęcie liminalności.

23 Tamże, s. 346.

${ }^{24}$ L. Kolankiewicz, Ku antropologii widowisk, [w:] Antropologia widowisk. Zagadnienia i wybór tekstów, red. L. Kolankiewicz, Warszawa 2005, s. 21.

${ }^{25}$ K. Pankowska, Drama. Konteksty teoretyczne, Warszawa 2013, s. 56.

26 Tamże, s. 57.

${ }^{27}$ M. Steiner, Geneza teatru w świetle antropologii kulturowej, Wrocław 2003, s. 284. 


\section{Liminalna faza rytuału przejścia a fenomen teatru}

Twórcą pojęcia rytuały przejścia jest Arnold van Gennep. Nazywał on nimi "sekwencje obrzędowe, które towarzyszą przechodzeniu z jednego stanu do innego, z jednego świata (w ujęciu kosmicznym lub społecznym) do drugiego" 28 . Konstatując, że w świecie społecznym można dostrzec rytm i stadialność podobną do tej, jaką rządzi się wszechświat, życie ludzkie postrzegał van Gennep nie jako continuum, ale jako ciąg przeskoków (przejść) $\mathrm{z}$ jednego stanu w kolejny. Za największy wkład van Gennepa w teorię rytuałów przejścia uważa się wyróżnienie i opisanie przez niego faz i traktowanie ich jako sekwencje obrzędowe. Przejście dokonuje się w trzech etapach, z których środkowy jest jakby momentem chwilowego zawieszenia między etapem pierwszym i drugim. Fazy te nazwał van Gennep: preliminalną (wyłączenie), liminalną (stan przejściowy), postliminalną (włączenie $)^{29}$. Żeby nastąpiła zmiana roli czy statusu społecznego jednostki, musi ona zostać na początku wyłączona ze "starego świata". Przez jakiś czas jej status jest zawieszony między dawną i nową rolą, między starą i nową tożsamością. Wreszcie następuje włączenie „do nowego świata”.

Myśl van Gennepa kontynuował Victor Turner i to jego poglądy są dla mnie kluczowe. Relację teatru i obrzędów definiuję właśnie za Turnerem i Richardem Schechnerem, których nazywa się antropologami performansów kulturowych. Mówi się nawet o modelu dramy społecznej TurneraSchechnera, ponieważ rdzeń ich teorii jest taki sam i obaj autorzy brali wzajemnie pod uwagę poglądy zawarte $\mathrm{w}$ swoich pracach ${ }^{30}$. Jak pisze Schechner, „Turner rozwinął odkrycia van Geneppa w teorię rytuału, która ma wielkie znaczenie dla dzisiejszej performatyki" 31 .

Można powiedzieć, że Turner dokonał przewrotu w teorii rytuałów odchodząc od Durkheimowskiego rozumienia ich jako zbiorowej reprezentacji odzwierciedlającej społeczeństwo i ubezpieczającej społeczną solidarność, uczynił z nich źródło generujące kulturę i strukturę². Rytuał postrzegał Turner jako coś, co ma moc przekształcania rzeczywistości, a nie tylko jej

${ }^{28}$ A. van Gennep, Obrzędy przejścia. Systematyczne studium ceremonii, przekł. B. Biały, Warszawa 2006, s. 37.

${ }^{29}$ Tamże, s. 45.

30 D. Avorgbedor, The Turner-Schechner Model of Performance as Social Drama: A ReExamination in the Light of Anlo-Ewe "Haló", Research in African Literatures, 1999, 30, 4: Drama and Performance, s. 150.

${ }^{31}$ R. Schechner, Performatyka. Wstęp, przekł. T. Kubikowski, Wrocław 2006, s. 76.

32 Por. V. Turner, Betwixt and Between: the Liminal Period in Rites of Passage, [w:] Betwixt and Between. Patterns of Masculine and Feminine Initation, red. L.C. Mahdi, S. Foster, M. Little, llinois 1987. 
potwierdzania ${ }^{33}$. Jak sam pisał o obrzędach przejścia: „rytuał nie jest tylko manifestacją transformacji, ale również jej duchem sprawczym"34. Turnera fascynowała szczególnie faza liminalna rytuałów przejścia, „ponieważ w niej dostrzegał on możliwość twórczego charakteru rytuału, możliwość, by tworzył on nowe sytuacje, tożsamości i rzeczywistości społeczne"35. Van Gennep przemiany w życiu człowieka postrzegał jako przekraczanie progu (limen). Turner podkreśla potencjał stanu liminalnego - jest to moment krytyczny, zwrotny, stan dekonstrukcji kulturowej, w którym wiele może się wydarzyć. Można go stymulować, tworząc bezprecedensowe kombinacje znanych elementów. Przestrzeniami, w których możliwe są takie działania na granicy fikcji i rzeczywistości są współcześnie między innymi przedstawienia teatralne, które dają możliwość kreowania liminalnych doświadczeń $^{36}$.

Liminalność rozumiana jako środkowa faza rytuałów przejścia staje się więc kategorią analizy innych fenomenów, w tym teatru. Richard Schechner pisząc o związkach rytuału i performansu artystycznego także podkreśla rolę liminalności, momentów progowych. Wąska przestrzeń limen, czyli progu, $\mathrm{w}$ dosłownym rozumieniu oddziela $\mathrm{w}$ domu dwa pomieszczenia, a także dom i świat zewnętrzny. W rytuale i sztuce przestrzeń ta poszerza się dosłownie i symbolicznie. „To, co zazwyczaj jest ledwie przejściem ku czemuś, staje się miejscem działania" 37 . Schechner przyrównuje tę fazę do warsztatu teatralnego, w którym poprzez dekonstrukcję treści kulturowych i ich ponowną konstrukcję odbywa się przygotowanie przedstawienia ${ }^{38}$. Autor za Turnerem rozróżnia przejścia liminalne i liminoidalne. Turner tymi drugimi nazywał fazę progową współczesnych rytuałów przejścia, w które, w przeciwieństwie do rytuałów plemiennych, wpisana jest opcjonalność. Przenosi to rytuały do sfery zabawy czy karnawału. Halloween, wieczory panieńskie i kawalerskie to rytuały, w których można brać udział, ale w każdej chwili można się wycofać właściwie bez konsekwencji. Inne jest też dziś zaangażowanie osób biorących udział w rytuale, dotyka innych płaszczyzn. Dlatego Schechner pisze o przemianie liminalnej i liminoidalnym „poruszeniu" czy też „tknięciu”39.

33 R.L. Grimes, Beggining in Ritual Studies, Columbia 1995, s. 167.

${ }^{34}$ V. Turner, Od rytuału do teatru: powaga zabawy, przekł. M. Dziekan, J. Dziekan, Warszawa 2005 , s. 128.

35 R. Schechner, Performatyka, s. 84 .

$36 \mathrm{~S}$. Lev-Aladgem, From ritual to drama and back in a rehabilitation day-care center, Journal of Aging Studies, 1999, 13, 3.

37 R. Schechner, Performatyka, s. 85.

${ }^{38}$ M. Steiner, Geneza teatru w świetle antropologii kulturowej, Wrocław 2003, s. 267.

${ }^{39}$ R. Schechner, Performatyka, s. 90. 
Aktorzy, sportowcy, tancerze, szamani, ludzie rozrywki, muzycy klasyczni - wszyscy trenują, ćwiczą i próbują, żeby móc na pewien czas „wyjść z siebie” i wejść całkowicie "W" to, co stanowi ich performans. W teatrze aktorzy robią na scenie coś więcej, niż tylko udają. Przeżywają oni podwójne przeczenie. Podczas gry nie są ani sobą, ani też postacią. Gra teatralna zachodzi pomiędzy „nie-ja”... „nie-ja?”40.

Według Turnera, typowe dla widowisk o charakterze liminalnym nie jest wkładanie masek i granie, ale właśnie ich zdzieranie, zrzekanie się ról, burzenie struktur. Rodzą się na ich miejsce nowe struktury „przypuszczająco-spełniające", jak nazywa to Turner. Antropolog widzi w nich moment dramatycznego napięcia, otwierający „tryb łączący”. Te struktury sytuują się $\mathrm{w}$ ramie zabawy, jednej z wielu ram typowych dla liminalności. $W$ ramie tej łączą się Batesonowskie procesy pierwotne i wtórne, na granicy nieświadomości i świadomości, snu i jawy. To, co podczas snu dzieje się poza świadomością śniącego w zabawie jest świadome, ale oznaczone jako „to tylko zabawa". Różnego rodzaju scenariusze, czy to teatralne czy też kulturowe, których autorem jest, jak określa to Turner, "tradycja”, są elementem procesów wtórnych. Treść scenariusza aktywowana jest jednak przez aktora, który znajduje się $\mathrm{w}$ stanie przypływu, czyli zespolenia procesu pierwotnego z wtórnym. Za sprawą tego zjawiska przekaz odciska się na aktorze i widowni, a dzieje się to $\mathrm{w}$ stanie liminalnym ${ }^{41}$. Z tej perspektywy teatr $\mathrm{w}$ ogóle, a fenomeny takie, jak teatr Jerzego Grotowskiego czy prace Felicitas Goodman to liminoidalne laboratoria inicjacji psychofizycznej ${ }^{42}$, bo tworzyli oni nowe doświadczenia liminoidalne działając na granicy symboli rytualnych i teatralnych.

Nie tylko teatr postrzegany jest przez własną liminalność. Dotyczy to także instytucji, jaką jest szkoła. Ta konstatacja i jej rozwinięcie stanowi kolejny etap moich analiz. Jest to ważna prawda o szkole dająca się przełożyć na wnioski dla praktyki, do czego zmierzam w tym tekście.

\section{Liminalność edukacji. Szkoła jako współczesny rytuał inicjacyjny}

Edukacja jest, czego dowodził na przykład R. Girard, następczynią praktyk wtajemniczenia i rytuałów przejścia, ich dzisiejszym wcieleniem ${ }^{43}$.

40 Tamże, s. 91.

${ }^{41}$ V. Turner, Liminalność i gatunki performatywne, przekł. K. Przyłuska-Urbanowicz, [w:] Rytuat, dramat, święto, spektakl. Wstęp do teorii widowiska kulturowego, red. J.J. MacAloon, Warszawa 2009, s. 52-53.

${ }^{42}$ R. Schechner, Przyszłość rytuału, przekł. T. Kubikowski, Warszawa 2000, s. 250.

${ }^{43}$ M. Dembiński, Rytualne oblicze lekcji. Studium teoretyczno-empiryczne, Kraków 2005, s. 29. 
W społeczeństwach wyłącznie rytualnych - konstatuje Girard - (...) rytualne i ofiarnicze sekwencje odgrywają już do pewnego stopnia rolę, która później przypadnie wszystkim instytucjom ${ }^{44}$.

W odniesieniu do szkoły chodzi szczególnie o rytuały przejścia45. Roman Schulz pisze, iż w większości podręczników wychowania obecna jest teza odnosząca się do upatrywania początków szkoły

w obyczajach ukształtowanych w okresie wspólnoty pierwotnej, a polegających na tzw. inicjacji, czyli odbywaniu przez młodzież pod okiem dorosłych, w odosobnieniu od reszty społeczności, celowych prób mających wykazać opanowanie umiejętności niezbędnych ludziom dorosłym ${ }^{46}$.

Jeśli tak patrzymy na szkołę, to możemy szukać także podobieństwa edukacji i rytuałów przejścia $\mathrm{w}$ zakresie funkcji, jakie pełnią. Rytuały w funkcjonalno-strukturalnym ujęciu służą podtrzymywaniu ciągłości społecznej. Rytuał, sam formalny i stały, jest „idealną reprezentacją ciągłości i trwałości" 47 , dlatego pierwotnie przypisywano mu rolę $\mathrm{w}$ podtrzymywaniu (przez potwierdzanie, oznajmianie, a nawet zaprowadzanie) społecznego status quo, analizowano go jako odbicie porządku społecznego. W tradycyjnych ujęciach rytuały postrzegane były jako element kultury podtrzymujący ciągłość społeczną, legitymizujący władzę ${ }^{48}$. Drugą funkcją, jaką dostrzegł w rytuałach przejścia Turner i która była przedmiotem analiz choćby Clifforda Geertza, jest zmiana. Jak pisze Timothy D. Son w odniesieniu do roli rytuałów $\mathrm{w}$ życiu zbiorowości, praktyki rytualne łączą te dwie siły edukacyjne w wysiłku stabilizowania poczucia zbiorowej tożsamości, jednocześnie ułatwiając jej transformację ${ }^{49}$. $Z$ jednej zatem strony rytuał służy przekazowi, konserwacji wartości, z drugiej towarzyszy zmianie.

Tak też postrzega się zinstytucjonalizowaną przestrzeń rytualną, jaką jest szkoła. $\mathrm{Z}$ jednej strony to tradycyjna transmisja kultury, z drugiej - prze-

${ }^{44}$ R. Girard, Widziałem szatana spadajacego z nieba jak błyskawica, przekł. E. Burska, Warszawa 2002, s. 103.

${ }^{45}$ Girard uważa, że w historii ludzkości były trzy etapy: rytuały bez instytucji, współistnienie instytucji i rytuałów, instytucje bez rytuałów. Dlatego egzaminy, przechodzenie z klasy do klasy, maturę traktuje jako analogię obrzędów przejścia. Nie widzi zaś, przeciwnie do jednej z głównych tez, które przyświecają mi w tym opracowaniu, możliwości postrzegania współczesności przez pryzmat jej rytuałów.

${ }^{46}$ R. Schulz, Szkoła - instytucja - system - rozwój, Torun 1992, s. 47.

47 Z. Mach, Rytuat, [w:] Encyklopedia socjologii, tom III, red. Z. Bokszański, A. Kojder, Warszawa 2000, s. 355.

${ }^{48}$ Ch. Hann, Antropologia społeczna, przekł. S. Szymański, Kraków 2008, s. 178.

${ }^{49}$ T.D. Son, Ritual Practices in Congregational Identity Formation, Lanham 2014, s. 2. 
strzeń przejściowa, liminalna, przestrzeń oporu50. Peter McLaren za Turnerem przyjął, że rytuały nie tylko kontrolują procesy społeczne, ale też je generują i zaproponował $\mathrm{w}$ analizach codzienności szkolnej stosować liminalne spojrzenia, pozwalające odnaleźć w szkole na przykład potencjał oporowy. Tym samym, swoje rozważania usytuował blisko poglądów Clifforda Geertza na proces rytualny i ludzkie działania jako nośniki sensu. W swoich badaniach chciał więc odkrywać "głęboką gramatykę" kultury szkolnej51. Nie podważał przy tym pierwszej funkcji, pisząc, iż to że rytuały i symbole rytualne często działają jako silne nośniki oczywistych wartości naszego społeczeństwa nie może być kwestionowane ${ }^{52}$.

Rozmaici autorzy, jak na przykład Johanningmeier ${ }^{53}$ czy Sergiovanni ${ }^{54}$, $\mathrm{w}$ odniesieniu do szkoły używają Turnerowskiego pojęcia betwixt and between, postrzegając szkołę jako przestrzeń przejściową zarówno w wymiarze czasu ludzkiego życia (między dzieciństwem i dorosłością), jak i jako przejściowe środowisko socjalizacyjne (między rodziną a szeroko rozumianym społeczeństwem). Vincent A. Anfara za Henrym Giroux przypomina, że młodzi ludzie muszą się buntować, by przejść od dziecięcej łatwowierności do dorosłego rozeznania poprzez młodzieńcze wątpliwości i rozczarowanie. Łamanie zasad i próbowanie się z wartościami, które odbywa się w murach szkoły, jest bezpieczniejsze niż to, jakie może mieć miejsce poza szkołą. Instytucja daje bezpieczną ramę młodzieńczych poszukiwań ${ }^{55}$. W tym sensie wychowawca staje się McLarenowskim nauczycielem na usługach liminalności. Powinien on towarzyszyć uczniowi jako partner w rytualnej podróży, jaką jest szkoła ${ }^{56}$.

Odczytanie szkoły jako rozwiniętej fazy liminalnej rytuału przejścia z dzieciństwa do dorosłości zatrzymuje nas na chwilę przy problemach typowych dla współczesnej inicjacji. Rytuały przejścia, które opisywał van

50 Zob. polskie badania szkoły z wykorzystaniem kategorii rytuał, np.: A. Babicka-Wirkus, Uczeń (nie) biega i (nie) krzyczy. Rytuały oporu jako przejaw autoekspresji młodzieży, Kraków 2015; M. Dembiński, Rytualne oblicze lekcji. Studium teoretyczno-empiryczne, Kraków 2005; M. Mendel, Przekraczanie progu szkolnego jako rite de passage, [w:] Pedagogika miejsca, red. M. Mendel, Wrocław 2006, s. 180-190; J. Szewczyk, Szkolne obrzędy i rytuaty w kontekście mitycznej podróży bohatera, Kraków 2002.

${ }^{51}$ P. McLaren, Edukacja jako system kulturowy, [w:] Nieobecne dyskursy, t. IV, red. Z. Kwieciński, Torun 1994, s. 6-7.

52 Tamże, s. 24.

53 E. Johanningmeier, The foundations of contemporary American education, Scottsdale 1987.

54 T. Sergiovanni, Leadership for the Schoolhouse: How Is It Different? Why Is It Important? San Francisco 1996.

55 V.A. Anfara, Urban Schools And Liminality, National Forum Journals, 1997, 10, s. 2-3.

56 P.L. McLaren, The Liminal Servant and the Ritual Roots of Critical Pedagogy, Language Arts, $1988,65,2$. 
Gennep, przeprowadzały młodego człowieka do nowego stanu szybko i w przewidywalny sposób. Dziś wygląda to zgoła inaczej. Adaptując koncepcję rozwoju psychospołecznego Erika Eriksona do współczesnego obrazu dorastania młodzieży, Jeffreya Arnett wskazuje na rozciąganie się moratorium w czasie i jego zmiany jakościowe ${ }^{57}$. Autorzy zajmujący się tym zjawiskiem, w tym na gruncie polskim na przykład Wanda Zagórka i Anna Lipska, wskazują wiele powodów takiego stanu rzeczy. Wśród nich wymieniają wzory wchodzenia $\mathrm{w}$ dorosłość, które charakteryzuje zanik rytuałów przejścia. Młodzież w społecznościach plemiennych przechodziła do dorosłości poprzez obrzęd, co miało wiele zalet. Wymieniłabym co najmniej pięć. Po pierwsze, wejście do dorosłości było bardzo konkretnym punktem w czasie. Niezależnie od tego, czy trwały dobę czy kilka tygodni, młody człowiek dokładnie wiedział, kiedy przekroczy próg dorosłości. Kiedy to się stało, $i$ jest to druga zaleta rytuału inicjacyjnego, nikt nie kwestionował zmienionego stanu nowicjusza. Po trzecie, sam inicjowany nie miał też wątpliwości, że zmiana zaszła, czemu służyła nie tylko powtarzalność rytuału, ale także jego intensywność. Odtworzona $\mathrm{w}$ nim śmierć i narodziny były nie tylko wymowne w warstwie symbolicznej, ale też działania w służbie tych symboli były niezwykle wyraziste. Neofita otrzymywał obowiązki i przywileje dorosłego i był jak dorosły traktowany. Po czwarte, inicjacja zachodziła $\mathrm{w}$ ideologicznych ramach wspólnoty, to znaczy w oparciu o znane, pewne wartości, jasne wytyczne. Wiadomo było skąd, dokąd i po co idzie młody człowiek. Po piąte wreszcie, procesowi stawania się dorosłym przewodniczyli i towarzyszyli członkowie wspólnoty, w tym (lub głównie) starszyzna, którzy zewnętrznie organizowali przebieg inicjacji, co pozwalało inicjowanemu tylko poddać się rytuałowi, bez konieczności jego organizowania i refleksji czy wszystko przebiega prawidłowo.

Oczywiście, można znaleźć wady każdego z tych punktów. Przecież rytuał taki indoktrynuje, odbiera wolność decydowania o sobie, odziera $\mathrm{z}$ indywidualizmu, a do tego wszystkiego w swojej intensywności bywa bolesny i okrutny (symboliczna śmierć adepta była odtwarzana na przykład poprzez jego fizyczne okaleczanie). Współczesne rytuały przejścia są za to jakby rozmyte: $\mathrm{w}$ czasie, $\mathrm{w}$ intensywności, $\mathrm{w}$ mocy sprawczej. Młodzi ludzie są $\mathrm{w}$ swoim dorastaniu pozostawieni sami sobie, to na nich spoczywa ciężar zorganizowania sobie swojego dorastania. Muszą sprostać wymaganiom, które stawia przez nimi dominująca $\mathrm{w}$ danym miejscu i czasie kultura, ale $\mathrm{w}$ dużej mierze muszą sobie poradzić $\mathrm{z}$ tym wyzwaniem sami.

57 Zob. np. J. Arnett, Emerging Adulthood: The Winding Road From the Late Teens Through the Twenties, Oxford 2004, s. 208-209; tejże, Conceptions of the Transition to Adulthood: Perspectives From Adolescence Through Midlife, Journal of Adult Development, 2001, 8, 2, s. 134. 
Ich quasi-inicjacja odbywa się (...) bez przewodnika, bez gotowego wzoru życia i ma często charakter nieświadomy. Nieraz na obrzeżach kultury, ulegając modom i współczesnym nurtom, uobecniają inicjacyjne scenariusze ${ }^{58}$.

Nic dziwnego, i mówił o tym zarówno Turner, jak i psycholodzy rozwojowi jak Zagórska, że ludzie organizują sobie sami rytuały przejścia. Rytuały odnajdywane są także $\mathrm{w}$ teatrze/poprzez teatr. Pojawia się potrzeba, by poprzez sztukę przezwyciężyć poczucie społecznej i jednostkowej fragmentacji59. Ludzie dostarczają sobie rytuałów także poprzez sport, w tym ekstremalny, poprzez podróże, $\mathrm{w}$ tym turystykę. Podróżowanie także może być ekstremalne, co pokazuje przykład turystyki śmierci. Są to wyjazdy do miejsc bardziej czy mniej bezpośrednio związanych ze śmiercią i cierpieniem. Jak pisze Anna Ziębińska-Witek, jedną z przyczyn podejmowania przez ludzi tego typu aktywności jest usunięcie śmierci ze współczesnego życia ${ }^{60}$. Osłabione znaczenie rytuałów pogrzebowych i w ogóle rytuałów oswajających przejścia między poszczególnymi etapami życia, w tym starzenia się i umierania sprawia, że tworzone są nowe rytuały z tym związane, na przykład właśnie tanoturystyka.

\section{Powrót do rytuałów poprzez dramę - kreowanie doświadczeń liminalnych}

Postulat powrotu do rytuału realizowany jest nie tylko $\mathrm{w}$ indywidualnych projektach życia i rozwoju. Pojawiają się próby organizowania rytuałów inicjacyjnych $\mathrm{w}$ formie programów edukacyjnych. Ze względu na podmiot moich zainteresowań, którym jest młodzież $\mathrm{w}$ okresie przejściowym, szczególnie zainteresował mnie projekt "The Rite Journey". Program, reklamowany jako "Transforming Today's Teens", wprowadzono w 2010 roku w wybranych szkołach dla chłopców w Nowej Zelandii. Jego twórcom przyświecała myśl, że chłopcom brakuje współcześnie struktur, kolektywnych rytuałów i wsparcia wspólnoty w procesie stawania się mężczyznami. Program ma dwa główne zadania: przekazywać wiedzę, jak stać się odpowiedzialnym mężczyzną i celebrować przejście do świata mężczyzn. Wieloletni program zakłada więc nie tylko rozmowy, dyskusje i inne zajęcia związane z przekazem wiedzy "starszyzny", ale także rywalizację sportową oraz

58 W. Zagórska, Uczestnictwo młodych dorostych w rzeczywistości wykreowanej kulturowo, Kraków 2004, s. 58.

59 R. Schechner, Performatyka, s. 102.

${ }^{60}$ A. Ziębińska-Witek, Turystyka śmierci jako zjawisko kulturowe, Teksty Drugie: teoria literatury, krytyka, interpretacja, 2012, 3(135), s. 178. 
takie ceremonie, jak na przykład „rytualne wyrzucanie kamieni”, na których chłopcy uprzednio zapisują coś, co symbolizuje ich dzieciństwo ${ }^{61}$.

Program ten wpisuje się $\mathrm{w}$ postrzeganie rytuałów jako elementu transmisji kulturowej i służy wzmacnianiu tradycyjnie rozumianych ról płciowych. W "The Rite Journey" są obecnie także programy dla dziewcząt. O programie dla chłopców na stronie internetowej programu czytamy:

Wiele lat temu, w tradycyjnych społecznościach, dorastaniu chłopców towarzyszyli mężczyźni, który uczyli ich jak zachowywać się jak mężczyźni na równi z uczeniem umiejętności koniecznych do życia w męskim świecie. W wieku 14 lat byli oni inicjowani do świata mężczyzn, a potem oczekiwało się on nich, że będą wypełniali swoje zadania jako mężczyźni w swojej społeczności. W dzisiejszym zachodnim świecie wielu chłopców doświadcza nieobecności mężczyzn. Ich matki są ich głównymi opiekunami aż do okresu dojrzewania, a przeciętny 14-letni mężczyzna miał do czynienia z nauczycielem mężczyzną przez około rok z całego czasu dotychczasowej nauki w szkole ${ }^{62}$.

\section{Odnośnie dziewcząt zaś czytamy:}

Wiele lat temu, $\mathrm{w}$ tradycyjnych społeczeństwach dziewczynki dorastały $\mathrm{w}$ towarzystwie kobiet, by poznać swoje prawdziwe Ja. Ich kształcenie i przygotowanie było zorganizowane wokół ich cyklicznej natury i tajemnic kobiecości. W dzisiejszej kulturze zachodniej większość dziewcząt będąc pod wpływem mediów i kultury popularnej jest niezadowolona $\mathrm{z}$ tego kim są, a przedwczesna seksualizacja ma miejsce bez żadnego znaczącego wsparcia63.

Z opisów tych wyziera ideologia stająca za programem "The Rite Journey". Według autorów, świat wyraźnie dzieli się na męski i kobiecy, chłopcy wychowywani przez kobiety nie mają szans na pełne wejście do tego męskiego świata, a dla dziewcząt najważniejsza jest ich biologia - cykliczna natura.

Obecność rytuałów w szkole często postrzegana jest właśnie jako narzędzie ideologizowania młodzieży, a tęsknota za nimi tożsama jest z tęsknotą za tradycyjnymi wartościami. Jest to więc jednocześnie tęsknota za rytuałem jako przekazem kulturowym. Typowy dla takiego ujęcia opis funkcji rytuałów w rozwoju dzieci odnajdujemy na przykład w tekście zatytułowanym The use of rituals at primary school. Martin Skutil, Lucie Jandošová i Veronika Makovičková piszą w nim, że

${ }^{61}$ A.P. Smith, The implementation of a rites of passage programme into a boys' secondary school, Pastoral Care in Education, 2012, 30, 4.

$62 \mathrm{http}: / /$ theritejourney.com/ boys-year-long-program [dostęp: 30.09.2016].

63 Tamże. 
rytuały pomagają stawiać dzieciom granice, które są im potrzebne i szczególnie ważne. Jasne zasady przysłużą się szczególnie tym dzieciom, które są niepewne i zdezorientowane (...). Nauczyciele, którzy są świadomi znaczenia rytuałów w życiu dziecka, włączają rytuały do szkolnej kultury, by uczniowie poczuli się bezpieczni w szkole. Rytuały pomagają promować pozytywną atmosferę, podkreślają unikalne wartości kultury szkoły i poszczególnych klas (...). Stosowanie rytuałów może mieć znaczący wpływ na klimat społeczny w klasach, a także na rozwój odpowiednich nawyków uczenia się, co może pozytywnie wpływać na uczniów 64 .

Podobnie postrzega się niejednokrotnie rolę dramy w szkole. Czyni to na przykład E. Szymik w podsumowaniu swojego artykułu o znaczeniu dramy w wychowaniu, pisząc:

drama jest skutecznym narzędziem w pracy dydaktyczno-wychowawczej, gdyż uczy zorganizowanej współpracy, skłania wszystkich uczniów do czynnego udziału w realizacji zadania i poczucia odpowiedzialności za nie, aktywizuje myślenie wychowanków (bowiem muszą odwoływać się do zdobytej wiedzy w celu rozwiązania problemu), uczy empatii, patrzenia na dany problem z różnych perspektyw, co pomaga młodzieży w redukowaniu konfliktów, doskonali zdolności komunikacyjne, relacje interpersonalne na płaszczyźnie: uczeń - nauczyciel oraz uczeń - uczeń, kształci umiejętność wyrażania własnych myśli i uczuć, przygotowuje młodzież do kreowania ról społecznych (co pozwala uczniowi poznać i doświadczyć siebie, okazywać wzajemne zrozumienie oraz pomoc w rozwiązywaniu problemów), motywuje uczniów do pracy nad własnym doskonaleniem (samokształceniem). (...) Poprzez tworzone fikcyjne zdarzenia i sytuacje oraz wchodzenie w role umożliwia nabywanie umiejętności w rozwiązywaniu konfliktów życiowych, w znacznym stopniu zapobiega agresji i przemocy wśród wychowanków. Uczniowie stają się bardziej kreatywni $\mathrm{w}$ rozwiązywaniu problemów związanych $\mathrm{z}$ zachowaniem $\mathrm{w}$ grupie, elastyczni, otwarci na drugiego człowieka, doznają głębokich przeżyć estetycznych. Metoda ta uczy pożądanych społecznie i psychologicznie zachowań, poszukiwania własnych wyborów i rozwiązań, przez co przyspiesza emocjonalne, intelektualne i społeczne dojrzewanie uczestników dramy ${ }^{65}$.

W opisie tym drama kreatywnie, w dobrej atmosferze, $\mathrm{z}$ naciskiem na empatię i samokształcenie służy mało twórczym i raczej utylitarnym celom: redukowaniu konfliktów, kreowaniu ról społecznych, uczeniu pożądanych zachowań. Nie można temu, rzecz jasna, zaprzeczyć - są to cele działań dramowych. Ale rytuał i drama mają też inne funkcje, wynikające z ich fazowego charakteru, co pośrednio pokazał Van Gennep, a przybliżali Turner, Schechner, czy Geertz. Chodzi o rolę rytuału w procesie zmiany. Rozwiązywanie konfliktów i zapobieganie agresji to hasła odwołujące się do włączają-

${ }^{64}$ M. Skutil, L. Jandošová, V. Makovičková, The use of rituals at primary school, International Journal of Human Sciences, 2012, (9)2, s. 1477-1478.

${ }^{65}$ E. Szymik, Znaczenie dramy w procesie wychowania, Studia i Prace Pedagogiczne, 2014, 1, s. 137. 
cej fazy rytuału przejścia. Należy jednak pamiętać o fazie środkowej, liminalnej, która jest konieczna, by rytuał zaistniał. Drama jako następczyni rytuałów przejścia ma w bezpiecznej atmosferze kreować sytuacje graniczne, liminalne, niebezpieczne. Ma piętrzyć problemy, potęgować konflikty rozwojowe, dynamizować relacje, bo tak działają fenomeny liminalne. Ma na to szanse w swojej intensywności (aktywności, emocji), znacznie większej niż $\mathrm{w}$ przypadku podających metod $\mathrm{w}$ nauczaniu i wychowaniu. Pokazuje to zresztą przywołana E. Szymik, pisząc wcześniej:

Odgrywana postać przejmuje wszystkie wypierane przez psychikę grającego cechy, najczęściej negatywne. Wcielanie się w role osób pozytywnych daje szansę realizacji marzeń, choćby na krótko ${ }^{66}$.

Autorka dostrzegając to $\mathrm{w}$ tekście, pomija we wnioskach pisząc już tylko o gaszeniu konfliktów. Tymczasem, takie bliskie katharsis czy rytualnego progu doświadczenie sublimuje przemoc, oczyszcza ją i oszukuje, jak za Girardem powtarza Schechner67.

Geertz w tekście zatytułowanym "Głęboka gra: uwagi o walkach kogucich na Bali" w tomie Interpretacja kultur. Wybrane eseje68 pokazuje, jak $\mathrm{w}$ formie rytualnej przeżywana jest agresja w codziennym życiu społecznym wycofana do podświadomości69. „Podczas walki kogutów przeżywane są, choć tylko na poziomie rytualnym, te ciemne pokłady świadomości, na których zasadza się pokojowe współżycie między ludźmi"70. Mężczyźni wystawiając do walki swoje koguty, na poziomie działania biorą udział w rozrywce, czynności są z poziomu ludycznej przyjemności. W warstwie znaczeniowej jednak walki kogutów sięgają dużo głębiej (stąd określenie Geertza „głęboka gra”). Jeśli weźmie się pod uwagę kontekst tych rytualnych rozgrywek, na przykład to, że koguty są oczkami w głowach mieszkańców Bali, mężczyźni opiekują się nimi jak dziećmi oraz symbolikę koguta, który jest zwierzęcym ucieleśnieniem cech męskich, dostrzegamy o co gra toczy się naprawdę. Celem jest rozładowanie istniejących napięć społecznych, tyle że $\mathrm{w}$ warstwie symbolicznej, na pograniczu (co typowe dla rytuału, teatru i dramy), fikcji i rzeczywistości. W wymiarze namacalnym wygrywa czy przegrywa kogut, w warstwie znaczeniowej, w którą przenosi akcję rytuał, rywalizują mężczyźni. Efekt, czyli wygrana lub przegrana dzia-

66 Tamże.

${ }^{67}$ R. Schechner, Przysztość rytuału, s. 226.

${ }^{68}$ C. Geertz, Interpretacja kultur. Wybrane eseje, przekł. M.M. Piechaczek, Kraków 2005.

${ }^{69}$ Tamże.

${ }^{70}$ J.J. Pawlik, Antropologiczne badanie rytuatu, [w:] Rytuat. Przeszłość i teraźniejszość, red. M. Filipiak, M. Rajewski, Lublin 2006, s. 28. 
ła w innej sferze niż się dzieje, co jest typowe zarówno dla rytuału jak i dramy.

Nie jest więc funkcją tak rytuału, jak i dramy tylko uładzanie i prostowanie do wzoru, ale także pomoc w uzewnętrznianiu konfliktów w przestrzeni przejściowej między rzeczywistością i fikcją.

Konflikt $\mathrm{w}$ dramie niezbędny jest do tworzenia wysokiego stanu napięcia wyzwalającego emocje. Jest to zabieg równoznaczny z katharsis, polegający na potęgowaniu gwałtownych uczuć, na ich wyładowaniu i wyzwoleniu się od nich ${ }^{71}$.

\section{Zakończenie}

\section{Jak zauważa Krzysztof Maliszewski:}

Kształcenie - o ile jest $\mathrm{w}$ istocie ksztatcace, czyli przybiera formę inicjacyjną - to nie proste znalezienie się $\mathrm{w}$ sytuacji nauczania, nie pokonanie jakiegoś formalnego szczebla oświatowego, nie dodanie do swoich zasobów nowej puli informacji lub nowej umiejętności, ale przewartościowanie, otwarcie horyzontu, przemiana stylu bycia ${ }^{72}$. I dalej: Na tym polega w istocie kształcenie - na odkotwiczającej konfrontacji ze światem, by z separacji i ze zderzenia wyłonić siebie samego na nowo. Dopiero oto paradoks - wystawienie się na próby i dotknięcia, a więc zachwianie własnym ja daje efekt jego regeneracji przez resyntezę ${ }^{73}$.

Rolą szkoły jest nie tylko przekazywanie wiedzy i wychowywanie. Jest nią także tworzenie liminalnej przestrzeni przymierzania tożsamości $\mathrm{w}$ drodze miedzy dzieciństwem i dorosłością oraz doświadczania własnej przejściowości.

Arpad Szakolczai pisze, jak ważne w życiu człowieka jest doświadczenie rytuału przejścia. Doświadczenie właśnie, z uwzględnieniem aspektu uczestnictwa. Nie można bowiem zrozumieć na przykład, co to znaczy być dorosłym. Trzeba tego doświadczyć ${ }^{74}$. Wśród metod nauczania i wychowania w szkole są takie, które bliższe są naturze doświadczalnie i takie, które są im dalsze. Do tych bliższych należy drama i tak właśnie ją postrzegam jako metodę pozwalającą na doświadczenie stanów liminalnych korzystnych dla rozwoju.

${ }^{71}$ P. Pindera, M. Pindera, Drama w procesie edukacji wczesnoszkolnej, Nauczyciel i Szkoła, 2002, 3-4, s. 170.

72 K. Maliszewski, Pedagogika na pograniczu światów. Eseje z cyklu „Medium Mundi”, Katowice 2015, s. 44.

73 Tamże, s. 48.

74 A. Szakolczai, Liminality and experience: structuring transitory situations and transformative events, International Political Anthropology, 2009, 2, 1, s. 147. 
Związkami dramy edukacyjnej i rytuałów, szczególnie zaś rytuałów inicjacyjnych, zainteresowałam się po lekturze kilka lat temu książki Pedagogika dramy. Teoria i praktyka. Krystyna Pankowska jeden z podrozdziałów zatytułowała „Inicjacja”. Zrelacjonowała w nim poglądy Claude Levi-Straussa na szkołę jako instytucję zastępującą plemienne rytuały przejścia, której rolą jest wprowadzanie młodego człowieka do świata dorosłości. Ponieważ jednak, co dalej wykłada za Straussem Pankowska, w szkołach przecenia się rolę zabawy, zanika jej funkcja inicjacyjna. Antidotum na tęsknotę za szkołą tradycyjną, w której środkami wychowawczymi są strach, upokorzenie, rygor i na przeciwstawną jej tęsknotę za bezstresową zabawą może być drama.

Stanowi ona bowiem model życia i jednocześnie jego ćwiczenie. W niektórych zatem sytuacjach daje szansę mierzenia i pokonywania trudnych problemów, przeciwności losu, daje szansę dorastania do dojrzałości i dorosłości ${ }^{75}$.

Drama edukacyjna pozwala uwewnętrznić wartości które niesie, nauczyć reagowania na pewne sytuacje, pobudzić do refleksji ${ }^{76}$. Jak określa to K. Pankowska, drama stanowi „współczesną szkolną namiastkę prawdziwej inicjacji młodego człowieka w dorosłe życie" 77 .

Drama jest metodą przepracowywania trudnych tematów dotyczących świata i własnej osoby. Służy pracy nad sobą78. Angażuje i emocje, i intelekt. Ludzie odgrywając role nietypowe dla siebie, mogą rzeczywiście zmieniać swoje poglądy i zachowania, przenosić wypracowane w dramie rozwiązania do realnego życia. Specyfika dramy polega na tym, że jej uczestnicy przyjmują role, nie zaś je odgrywają. Nie ma scenariuszy, a celem działań dramowych jest przygotowanie do rozumienia różnych sytuacji i pokonywania trudności. Nie odbierając zabawie ważnych walorów rozwojowych, dramę postrzegamy szerzej niż zabawę. Staje się ona modelem i ćwiczeniem życia "Zamieniając swoje 'ja' na 'rolę' człowiek uzyskuje pozwolenie na zachowania, które normalnie są trudne do wykonania"79. I może korzystać z ogromnego potencjału doświadczania liminalności.

\section{BIBLIOGRAFIA}

Antczak M., Techniki dramy w teorii i praktyce nie tylko dla nauczycieli bibliotekarzy, Agencja Sukurs, Warszawa 2004.

${ }^{75}$ K. Pankowska, Pedagogika dramy, s. 206.

76 Tamże, s. 58.

77 Tamże, s. 206.

78 G. Özbek, Drama in education, s. 59.

${ }^{79}$ K. Pankowska, Pedagogika dramy, s. 223. 
Anfara V.A., Urban Schools And Liminality, National Forum Journals, 1997, 10.

Arnett J., Emerging Adulthood: The Winding Road From the Late Teens Through the Twenties, Oxford University Press, Oxford 2004.

Arnett J., Conceptions of the Transition to Adulthood: Perspectives From Adolescence Through Midlife, Journal of Adult Development, 2001, 8, 2.

Avorgbedor D., The Turner-Schechner Model of Performance as Social Drama: A ReExamination in the Light of Anlo-Ewe "Haló", Research in African Literatures, 1999, 30, 4: Drama and Performance.

Babicka-Wirkus A., Uczeń (nie) biega i (nie) krzyczy. Rytuaty oporu jako przejaw autoekspresji młodzieży, Oficyna Wydawnicza Impuls, Kraków 2015.

Dembiński M., Rytualne oblicze lekcji. Studium teoretyczno-empiryczne, Oficyna Wydawnicza Impuls, Kraków 2005.

Eller J.D., Antropologia kulturowa. Globalne sity, lokalne światy, przekł. A. Gąsior-Niemiec, Wydawnictwo Uniwersytetu Jagiellońskiego, Kraków 2012.

Geertz C., Interpretacja kultur. Wybrane eseje, przekł. M.M. Piechaczek, Wydawnictwo Uniwersytetu Jagiellońskiego, Kraków 2005.

Girard R., Widziatem szatana spadającego z nieba jak btyskawica, przekł. E. Burska, Instytut Wydawniczy PAX, Warszawa 2002.

Grimes R.L., Beginnings in Ritual Studies, University of South Carolina Press, Columbia 1995.

Hann Ch., Antropologia społeczna, przekł. S. Szymański, Wydawnictwo Uniwersytetu Jagiellońskiego, Kraków 2008.

http:/ / theritejourney.com/boys-year-long-program [dostęp: 30.09.2016].

http://theritejourney.com/girls-year-long-program/ [dostęp: 30.09.2016].

Jaskulska S., Motyl K., Gra o Tron? Rytuaty i gry w optyce teorii antropologicznej Clifforda Geertza i analizy transakcyjnej. Przyczynek do badania codzienności szkoty, Studia Edukacyjne, 2014, 31.

Jerzak-Gierszewska T., Religia a magia. Klasyczne koncepcje antropologiczne, Wydawnictwo Fundacji Humaniora, Poznań 1995.

Johanningmeier E., The foundations of contemporary American education, Gorsuch Scarisbrick, Scottsdale 1987.

Jurkowski H., Materiat jako wehikuł treści rytuału, Wydawnictwa Uniwersytetu Warszawskiego, Warszawa 2011.

Kolankiewicz L., Ku antropologii widowisk, [w:] Antropologia widowisk. Zagadnienia i wybór tekstów, red. L. Kolankiewicz, Wydawnictwa Uniwersytetu Warszawskiego, Warszawa 2005.

Królica M., Drama i happening w edukacji przedszkolnej, Oficyna Wydawnicza Impuls, Kraków 2009.

Lev-Aladgem S., From ritual to drama and back in a rehabilitation day-care center, Journal of Aging Studies, 1999, 13, 3.

Mach Z., Rytuat, [w:] Encyklopedia socjologii, tom III, red. Z. Bokszański, A. Kojder, Oficyna Naukowa, Warszawa 2000.

Maliszewski K., Pedagogika na pograniczu światów. Eseje z cyklu „Medium Mundi", Wydawnictwo Uniwersytetu Śląskiego, Katowice 2015.

Mauss M., Hubert H., Zarys ogólnej teorii magii, [w:] Socjologia $i$ antropologia, red. M. Mauss, przekł. M. Król, J. Szacki, K. Pomian, Państwowe Wydawnictwo Naukowe, Warszawa 1973. 
McLaren P., The Liminal Servant and the Ritual Roots of Critical Pedagogy, Language Arts, $1988,65$.

McLaren P., Edukacja jako system kulturowy, [w:] Nieobecne dyskursy, t. IV, red. Z. Kwieciński, Wydawnictwo Uniwersytetu Mikołaja Kopernika, Torun 1994.

Mendel M., Przekraczanie progu szkolnego jako rite de passage, [w:] Pedagogika miejsca, red. M. Mendel, Wydawnictwo Naukowe Dolnośląskiej Szkoły Wyższej Edukacji TWP, Wrocław 2006.

Nowak-Wolna K., Od dramatu teatralnego do dramy edukacyjnej, [w:] Od teatru pedagogicznego do teatru terapeutycznego, red. W. Sikorski, A. Sikorska, Wydawnictwo Difin, Warszawa 2014.

Özbek G., Drama in education: key conceptual features, Journal of Contemporary Educational Studies, 2014, 1.

Pankowska K., Drama - zabawa i myślenie, Centralny Ośrodek Metodyki Upowszechniania Kultury, Warszawa 1990.

Pankowska K., Pedagogika dramy. Teoria i praktyka, Wydawnictwo Akademickie Żak, Warszawa 2000.

Pankowska K., Drama. Konteksty teoretyczne, Wydawnictwa Uniwersytetu Warszawskiego, Warszawa 2013.

Pawlik J.J., Antropologiczne badanie rytuału, [w:] Rytuat. Przeszłość i teraźniejszość, red. M. Filipiak, M. Rajewski, Wydawnictwo Uniwersytetu Marii Curie-Skłodowskiej, Lublin 2006.

Pindera P., Pindera M., Drama w procesie edukacji wczesnoszkolnej, Nauczyciel i Szkoła, 2002, 3-4.

Rappaport R., Rytuat i religia w rozwoju ludzkości, Zakład Wydawniczy Nomos, Kraków 2008.

Rothenbuhler E., Komunikacja rytualna. Od rozmowy codziennej do ceremonii medialnej, przekł. J. Barański, Wydawnictwo Uniwersytetu Jagiellońskiego, Kraków 2006.

Schechner R., Przyszłość rytuału, przekł. T. Kubikowski, Oficyna Wydawnicza Volumen, Warszawa 2000.

Schechner R., Performatyka. Wstęp, przekł. T. Kubikowski, Ośrodek Badań Twórczości Jerzego Grotowskiego i Poszukiwań Teatralno-Kulturowych, Wrocław 2006.

Schulz R., Szkoła - instytucja - system - rozwój, Wydawnictwo Edytor, Torun 1992.

Sergiovanni T., Leadership for the Schoolhouse: How Is It Different? Why Is It Important?, Jossey-Bass Publishers, San Francisco 1996.

Skutil M., Jandošová L., Makovičková V., The use of rituals at primary school, International Journal of Human Sciences, 2012, (9)2.

Smith A.P., The implementation of a rites of passage programme into a boys' secondary school, Pastoral Care in Education, 2012, 30, 4.

Son T.D., Ritual Practices in Congregational Identity Formation, Lexington Books, Lanham 2014.

Steiner M., Geneza teatru w świetle antropologii kulturowej, Wydawnictwo Uniwersytetu Wrocławskiego, Wrocław 2003.

Szakolczai A., Liminality and experience: structuring transitory situations and transformative events, International Political Anthropology, 2009, 2, 1.

Szewczyk J., Szkolne obrzędy i rytuaty w kontekście mitycznej podróży bohatera, Oficyna Wydawnicza Impuls, Kraków 2002.

Szymik E., Znaczenie dramy w procesie wychowania, Studia i Prace Pedagogiczne, 2014, 1. 
Turner V., Betwixt and Between: the Liminal Period in Rites of Passage, [w:] Betwixt and Between. Patterns of Masculine and Feminine Initation, red. L.C. Mahdi, S. Foster, M. Little, Open Court Publishing, Illinois 1987.

Turner V., Od rytuatu do teatru: powaga zabawy, przekł. M. Dziekan, J. Dziekan, Oficyna Wydawnicza Volumen, Warszawa 2005.

Turner V., Liminalność i gatunki performatywne, przekł. K. Przyłuska-Urbanowicz, [w:] Rytuat, dramat, święto, spektakl. Wstęp do teorii widowiska kulturowego, red. J.J. MacAloon, Wydawnictwa Uniwersytetu Warszawskiego, Warszawa 2009.

Way B., Development through drama, Longman, London 1968.

Way B., Drama w wychowaniu dzieci i młodzieży, przekł. K. Pankowska, E. Nerwińska, Wydawnictwa Szkolne i Pedagogiczne, Warszawa 1995.

Witerska K., Drama. Przewodnik po koncepcjach, technikach i miejscach, Wydawnictwo Difin, Warszawa 2014.

van Gennep A., Obrzędy przejścia. Systematyczne studium ceremonii, przekł. B. Biały, Państwowy Instytut Wydawniczy, Warszawa 2006.

Zagórska W., Uczestnictwo młodych dorostych w rzeczywistości wykreowanej kulturowo, Towarzystwo Autorów i Wydawców Prac Naukowych Universitas, Kraków 2004.

Ziębińska-Witek A., Turystyka śmierci jako zjawisko kulturowe, Teksty Drugie: teoria literatury, krytyka, interpretacja 2012, 3(135). 